\title{
Analysis of the adaptability of black bean cultivars by means of quantile regression
}

\author{
Laís Mayara Azevedo Barroso ${ }^{1^{*}, 2}$ (D) Moysés Nascimento ${ }^{1}$ Leiri Daiane Barili $^{3}$ \\ Ana Carolina Campana Nascimento ${ }^{1}$ Naine Martins do Vale ${ }^{3}$ Fabyano Fonseca e Silva ${ }^{4}$ \\ José Eustáquio de Souza Carneiro ${ }^{3}$
}

\author{
${ }^{1}$ Departamento de Estatística, Centro de Ciências Exatas e Tecnológicas, Universidade Federal de Viçosa (UFV), Avenida P.H. Rolfs, \\ 36570-000, Viçosa, MG, Brasil. E-mail: lais.azevedobarroso@gmail.com. *Corresponding author. \\ ${ }^{2}$ Departamento de Matemática e Estatística, Universidade Federal de Rondônia (UNIR), Ji-Paraná, RO, Brasil. \\ ${ }^{3}$ Departamento de Fitotecnia, Universidade Federal de Viçosa (UFV), Viçosa, MG, Brasil. \\ ${ }^{4}$ Departamento de Zootecnia, Universidade Federal de Viçosa (UFV), Viçosa, MG, Brasil.
}

ABSTRACT: The aim of this study was to use quantile regression $(Q R)$ to characterize the effect of the adaptability parameter throughout the distribution of the productivity variable on black bean cultivars launched by different national research institutes (research centers) over the last 50 years. For this purpose, 40 cultivars developed by Brazilian genetic improvement programs between 1959 and 2013 were used. Initially, QR models were adjusted considering three quantiles $(\tau=0.2,0.5$ and 0.8$)$. Subsequently, with the confidence intervals, quantile models $\tau=0.2$ and $0.8\left(Q R_{02}\right.$ and $\left.Q R_{0.8}\right)$ showed differences regarding the parameter of adaptability and average productivity. Finally, by grouping the cultivars into one of the two groups defined from $Q R_{0.2}$ and $Q R_{0.8}$, it was reported that the younger cultivars were associated to the quantile $\tau=0.8$, i.e., those with higher yields and more responsive conditions indicating that genetic improvement over the last 50 years resulted in an increase in both the productivity and the adaptability of cultivars.

Key words: gene-environment (GxE) interaction, Phaseolus vulgaris L., genetic improvement, quantiles, regression models.

Análise da adaptabilidade de cultivares de feijão preto por meio de regressão quantílica

RESUMO: Neste estudo objetivou-se utilizar a regressão quantílica (RQ) para caracterizar o efeito do parâmetro de adaptabilidade ao longo de toda a distribuição da variável produtividade em cultivares de feijão preto lançadas por diferentes instituições nacionais de pesquisa nos últimos 50 anos. Para tanto utilizou-se 40 cultivares desenvolvidas pelos programas brasileiros de melhoramento genético entre os anos de 1959 a 2013. Inicialmente foram ajustados modelos de $R Q$ considerando três quantis $(\tau=0,2,0,5,0,8)$. Posteriormente, com os intervalos de confiança verificou-se que os modelos quantílicos $\tau=0,2$ e $0,8\left(R Q_{0,2}\right.$ e $\left.R Q_{0,8}\right)$ apresentaram diferenças quanto ao parâmetro de adaptabilidade e produtividade média. Finalmente, por meio do agrupamento das cultivares em um dos dois grupos definidos a partir de $R Q_{0,2}$ e $R Q_{0,8}$, constatou-se que as cultivares mais novas foram associadas ao quantil $\tau=0,8$, ou seja, aquelas com maiores produtividades e mais responsivas as condições ambientais indicando que o melhoramento ao longo dos últimos 50 anos possibilitou o incremento tanto na produtividade quanto na adaptabilidade das cultivares.

Palavras-chave: Interação GE, Phaseolus vulgaris L., melhoramento genético, quantis, modelos de regressão.

\section{INTRODUCTION}

Brazil is the world's largest producer and consumer of beans (Phaseolusvulgaris L.) and reached 3.39 million tons in the 2016/2017 harvest (CONAB, 2017).Genetic improvement has contributed significantly to this production (or productivity) growth over the last decades.

In a genetic improvement program, when the objective is to recommend genotypes for cultivation, it is necessary to consider the interaction between genotype and environment (GxE). The GxE interaction is defined as the differential of the genotype response in connection with the environmental variation (COUTO et al., 2015). Effect of the GE interaction can be reduced by recommending more stable and well-adapted genotypes to be used in different environments through adaptability and phenotypic stability analyses.

In order to recommend genotypes with wide adaptation, there are a large number of studies on the adaptability and stability of bean cultivars (PEREIRA et al., 2009; SILVA et al., 2013). Recently, aiming to evaluate the increase in productivity and the adaptation and predictability of black bean cultivars, BARILI et al. (2015) estimated the average grain yield as well as the adaptability and phenotypic stability parameters of genotypes developed by the main Brazilian genetic improvement programs between 1959 and 2013. According to these 
researchers, genetic improvement programs have contributed to an increase of productivity as new cultivars are recommended.

Although interesting, such studies evaluate the adaptability in average terms, i.e., the correlation between environmental variation $(\mathrm{X})$ and phenotypic response $(\mathrm{Y})$ is explained by conditional expectation $\mathrm{E}(\mathrm{Y} \mid \mathrm{X})$. In order to obtain information on different levels of the productivity variable, BARROSO et al. (2015) proposed the use of quantile regression (KOENKER \& BASSET, 1978) for adaptability and stability studies considering 92 genotypes of alfalfa (Medicago sativa L.) assessed in 20 different environmental conditions. In order to explain the functional relationship between the environmental variation $(\mathrm{X})$ and the phenotypic response $(\mathrm{Y})$, this method, unlike the methods based on linear regression (EBERHART \& RUSSELL, 1966) provides a generalized explanation for any quantile of phenotypic values. Therefore, the quantile regression (QR) may be used in all situations that the usual regression methods can be applied. However, it allows that more detailed information about the phenomenon under study is gathered (NASCIMENTO et al., 2018; PUIATTI et al., 2018). Specifically, unlike the study carried out by BARILI et al. (2015), if we consider the entire set of genotypes under study for the adjustment, they were able to characterize the effect of the adaptability parameter along the entire distribution of observed productivity values.

In view of the above mentioned, the present study aimed to characterize the adaptability of black bean cultivars recommended by different national research institutes over the last 50 years (from 1959 to 2013), according to the distribution of the observed values of grain yield, from of the quantile regression analysis $(\mathrm{QR})$.

\section{MATERIALS AND METHODS}

We used data from experimental trials conducted at the Experimental Stations of the Universidade Federal de Viçosa (UFV) in the municipalities of Viçosa (latitude: $20^{\circ} 45^{\circ} 14^{\prime \prime} \mathrm{S}$, longitude: $42^{\circ} 52^{\prime} 55^{\prime}$ ' $\mathrm{W}$ and altitude: $648 \mathrm{~m}$ ) and Coimbra, state of Minas Gerais (MG), southeast Brazil (latitude $20^{\circ} 51^{\prime} 24$ ' S, longitude $42^{\circ} 48^{\prime} 10^{\prime} \mathrm{W}$, and altitude of $720 \mathrm{~m}$ ) during the drought crop and winter crops of 2013 characterizing 4 different environments. In these experiments, which consisted of a randomized blocks with three replicates, the grain

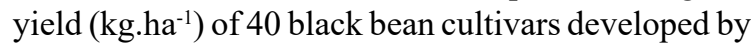
the Brazilian genetic improvement programs between 1959 and 2013 was evaluated (Table 1).
Initially, the analysis of joint variance was performed to detect any GxE interaction. Once a GxE interaction was detected, we used the QR (KOENKER $\&$ BASSET, 1978) to characterize the adaptability of 40 black bean cultivars as suggested by BARROSO et al. (2015) for adaptability and stability studies. It should be emphasized that the concept of adaptability used in QR models is similar to the one described by EBERHART \& RUSSELL (1966); i.e., adaptability refers to the ability of cultivars to benefit from the environment.

BARROSO et al., (2015) suggested that the following model of quantile regression is used in studies of adaptability and phenotypic stability:

$$
Y_{i j}=\beta_{0 i}(\tau)+\beta_{1 i}(\tau) I_{j}+\varepsilon_{i j}
$$

in which $Y_{i j}$ are the grain yield values of the cultivar evaluated in $\mathrm{j}$ environments; $I_{j}$ are the values of the coded environmental index; $\beta_{0 \mathrm{i}}(\tau)$ refers to the intercept of each cultivar (average productivity); $\beta_{1 \mathrm{i}}(\tau)$ is the coefficient of regression of each cultivar (parameter of adaptability), and is the same indicator of the effect of environmental improvement in quantiles of the distribution of productivity; and $\tau$ indicates the quantile of interest.

In the present study, unlike the study carried out by BARROSO et al. (2015), quantile models are adjusted considering all cultivars simultaneously; i.e., the adjusted model is given by:

$$
Y_{k}=\beta_{0}(\tau)+\beta_{1}(\tau) I_{k}+\varepsilon_{k}
$$

in which are the grain yield values of all cultivars evaluated in the $\mathrm{k}$ environments; $I_{k}$ are the values of the coded environmental index; $\beta_{0}(\tau)$ refers to the intercept (average productivity); $\beta_{1}(\tau)$ is the regression coefficient (parameter of adaptability), and is the same indicator of the effect of environmental improvement on the quantiles of productivity distribution; and indicates the quantile of interest. Therefore, we are able to study the effect of the adaptability parameter along the distribution of the phenotypic values. Three quantiles, $\tau=0.1,0.5$ and 0.8 , were considered.

Adjusted quantile regression for this study consisted of obtaining the estimates of the parameters $\hat{\beta}(\tau)=\left[\beta_{0}(\tau), \hat{\beta}_{1}(\tau),\right]^{T}$ of the 40 cultivars assessed in 4 differents environments (160 observations in total) by means of the solution of the following optimization problem: 
$\beta(\tau)=\operatorname{argmin}_{\beta}\left\{\sum_{k=1}^{160} \rho_{\tau}\left[Y_{k}-\beta_{0}(\tau)-\beta_{1}(\tau) I_{k}\right]\right\}$

The check function (KOENKER \& BASSETT, 1978), $\rho_{\tau}($.$) is given by:$

$\rho_{\tau}\left[Y_{k}-\beta_{0}(\tau)-\beta_{1}(\tau) I_{k}\right]=\left\{\begin{array}{l}{\left[Y_{k}-\beta_{0}(\tau)-\beta_{1}(\tau) I_{k}\right], \text { if } Y_{k}-\beta_{0}(\tau)-\beta_{1}(\tau) I_{k} \geq 0} \\ -(1-\tau)\left[Y_{k}-\beta_{0}(\tau)-\beta_{1}(\tau) I_{k}\right], \text { otherwise. }\end{array}\right.$

In order to verify that the coefficients of the quantile regression model $\left(\beta_{0}(\tau)\right.$ and $\left.\beta_{1}(\tau)\right)$ differ between the equations adjusted for the three quantiles $(\tau=0.2$, $0.5,0.8)$ the confidence intervals for the 3 models were obtained. The $95 \%$ confidence intervals were constructed based on the ranks inversion test since it is mildly affected by problems of heterogeneity (KOENKER, 1994).

Finally, after adjustment and construction of the confidence intervals of the different models, each cultivar was classified into one of the groups formed, defined by different regression coefficients (adaptability parameter). The criterion used to insert the cultivar in one of the groups previously defined by means of the confidence interval was the lowest value of the Euclidian distance between the grain yield value of the same and the value estimated by the adjusted QR models. This procedure aimed the formation of groups that present different adaptability patterns throughout the distribution of phenotypic values. As a result, we are able to assess if newer genotypes are associated with the adjusted equation for high values of grain yield.

All analyses were performed using the software R (R CORE TEAM, 2018). The adjustment of the QR model was performed using the $r q$ function of the quantreg package (KOENKER et al., 2017), and the Euclidean distance calculation was performed by means of the function dist from the R software base.

\section{RESULTS AND DISCUSSION}

The analysis of combined variance revealed a significant effect of all factors, showing a differentiated response of bean cultivars to

Table 1- Identification of 40 black bean cultivars (Phaseolus vulgaris L.) grown by research institutes in Brazil.

\begin{tabular}{|c|c|c|c|c|c|c|c|}
\hline Cultivar & Year & Institute $^{*}$ & QR & Cultivar & Year & Institute $^{*}$ & QR \\
\hline Rico 23 & 1959 & UFV & 0.2 & Ouro Negro & 1992 & EMBRAPA & 0.2 \\
\hline Rio Tibagi & 1971 & IAPAR & 0.2 & Onix & 1992 & EMGOPA & 0.2 \\
\hline Capixaba Precoce & 1980 & EMCAPA & 0.2 & BR-IPA 10 & 1992 & IPA & 0.2 \\
\hline Moruna & 1980 & IAC & 0.2 & IAPAR 65 & 1993 & IAPAR & 0.2 \\
\hline IRAÍ & 1981 & IPAGRO & 0.2 & Xamego & 1993 & EMGOPA & 0.2 \\
\hline Milionário 1732 & 1983 & EPAMIG & 0.2 & IAC-Una & 1994 & IAC & 0.8 \\
\hline Rico 1735 & 1983 & EPAMIG & 0.2 & IPR Uirapurú & 2000 & IAPAR & 0.8 \\
\hline IAPAR 8-Rio Negro & 1983 & IAPAR & 0.2 & BRS Valente & 2001 & EMBRAPA & 0.8 \\
\hline BR-2 Grande Rio & 1985 & PESAGRO & 0.2 & IPR Graúna & 2002 & IAPAR & 0.8 \\
\hline BR-3 Ipanema & 1985 & PESAGRO & 0.2 & BRS Campeiro & 2003 & EMBRAPA & 0.8 \\
\hline BR 1- Xodó & 1985 & PESAGRO & 0.2 & BRS Grafite & 2003 & EMBRAPA & 0.8 \\
\hline FT 120 & 1986 & FT-Sementes & 0.2 & BRS Supremo & 2004 & EMBRAPA & 0.8 \\
\hline IAPAR 20 & 1987 & IAPAR & 0.2 & IAC-Tunã & 2005 & IAC & 0.8 \\
\hline BR-IPAGRO 2-Pampa & 1989 & EMCAPA & 0.2 & BRS Esplendor & 2006 & EMBRAPA & 0.8 \\
\hline BR-IPAGRO 1-Macanudo & 1989 & IPAGRO & 0.2 & IPR Gralha & 2006 & IAPAR & 0.8 \\
\hline BR 6-Barriga verde & 1990 & EMPASC & 0.2 & IPR Tiziu & 2006 & IAPAR & 0.8 \\
\hline IAPAR 44 & 1990 & IAPAR & 0.2 & BRS Expedito & 2007 & EMBRAPA & 0.8 \\
\hline Preto Uberabinha & 1990 & IPEACO/MG & 0.2 & IPR Tuiuiu & 2010 & IAPAR & 0.8 \\
\hline Varre-Sai & 1991 & PSAGRO/RJ & 0.2 & VP 22 & 2013 & UFV & 0.8 \\
\hline Diamante Negro & 1991 & EMBRAPA & 0.8 & VP 33 & 2013 & UFV & 0,8 \\
\hline
\end{tabular}

"UFV: Federal University of Viçosa; IAPAR: Agronomic Instituto of Paraná; EMCAPA: Capixaba Company of Agricultural Research; IAC: Agronomic Institute; IPAGRO: Institute of Agronomic Research; EPAMIG: COMPANY OF AGRICULTURAL RESEARCH OF MINAS GERAIS; PESAGRO: Agricultural Research Company of RJ; EMPASC: Catarinense Company of Agricultural Research; IPEACO/MG: Agricultural Research and Experimentation Institute of Central-West Brazil; EMBRAPA: Brazilian Agricultural Research Corporation 
environmental changes as presented in table 2 from BARILI et al. (2015). Differentiated yield response of bean genotypes in different environments was also observed by RIBEIRO et al. (2008) and MOURA et al. (2013).

The estimated values for $\hat{\beta}_{0}(\tau)$ and $\hat{\beta}_{1}(\tau)$ and their respective confidence intervals $(\alpha=0.05)$ for the 3 models adjusted by $\mathrm{QR}$ are shown in Figures $1 \mathrm{~A}$ and 1B. According to figures $1 \mathrm{~A}$ and $1 \mathrm{~B}$, it is possible to observe that the intercept and the adaptability parameter presented an increasing trend along the distribution (quantiles) of the phenotypic values of productivity.

In general, the $95 \%$ confidence intervals, presented in Figure 1, indicated that both the average productivity, $\hat{\beta}_{0}(\tau)$, and the adaptability parameter differ along the distribution of phenotypic productivity values. Specifically, average productivity increases as assessed quantiles increase accordingly. Moreover, it can be seen that for the 3 quantiles evaluated $(\tau=0.2$, $0.5,0.8)$, the average productivity, $\hat{\beta}_{0}(\tau)$ differs from the average productivity of the experiment $\left(2797.7 \mathrm{~kg} \cdot \mathrm{ha}^{-1}\right.$, dashed line) (Figure 1A). In terms of the adaptability parameter, it is observed that it presents different values of the unit (general adaptability according to EBERHART \& RUSSEL, 1966) for the extreme quantile $(\tau=0.2$ and $\tau=0.8)$ of the distribution of phenotypic values of productivity (Figure 1B). These results indicated that less productive cultivars have a lower response to environmental improvement when compared to more productive cultivars (Figure 1B). The estimated equations for the quantiles 0.2 and
0.8 were, respectively, $y_{k}=2359.18+0.85 I_{k}$ and $y_{k}=$ $3286.10+1.24 I_{k}$ and are shown in figure 2 .

After observing differences in terms of the adaptability parameter for the extreme quantiles ( $\tau=0.2$ and 0.8 ), each cultivar was then classified into one of the two groups using as criterion the lowest value of the Euclidean distance between the productivity value of grains of the same and the value estimated by the adjusted QR models. After the grouping, a total of 24 and 16 cultivars were classified in groups $\mathrm{QR}_{0.2}$ and $\mathrm{QR}_{0.8}$, respectively (Table 1).In addition, it was noted that the cultivars more recently are those that present higher productivity, and therefore, are more responsive to environment improvement (Table 1).

Specifically, the cultivars recommended until 1993 were classified as belonging to the group represented by the model $\mathrm{QR}_{0.2}$ whereas those most recently recommended (after 1993), were classified in the group represented by model $\mathrm{QR}_{0.8}$. In view of these results, we noted that the most recent cultivars (those that were introduced over the last 15 years) present higher productivity and are more responsive to environmental improvement. BARILI et al. (2015) noted that genetic improvement programs have contributed to the increase of grain yield with the recommendation of new cultivars.

According to RAMALHO et al. (2012), the increase in grain yield in the bean crop in the country observed in the last decades reflect a continuous action of the Brazilian research institutes in activities

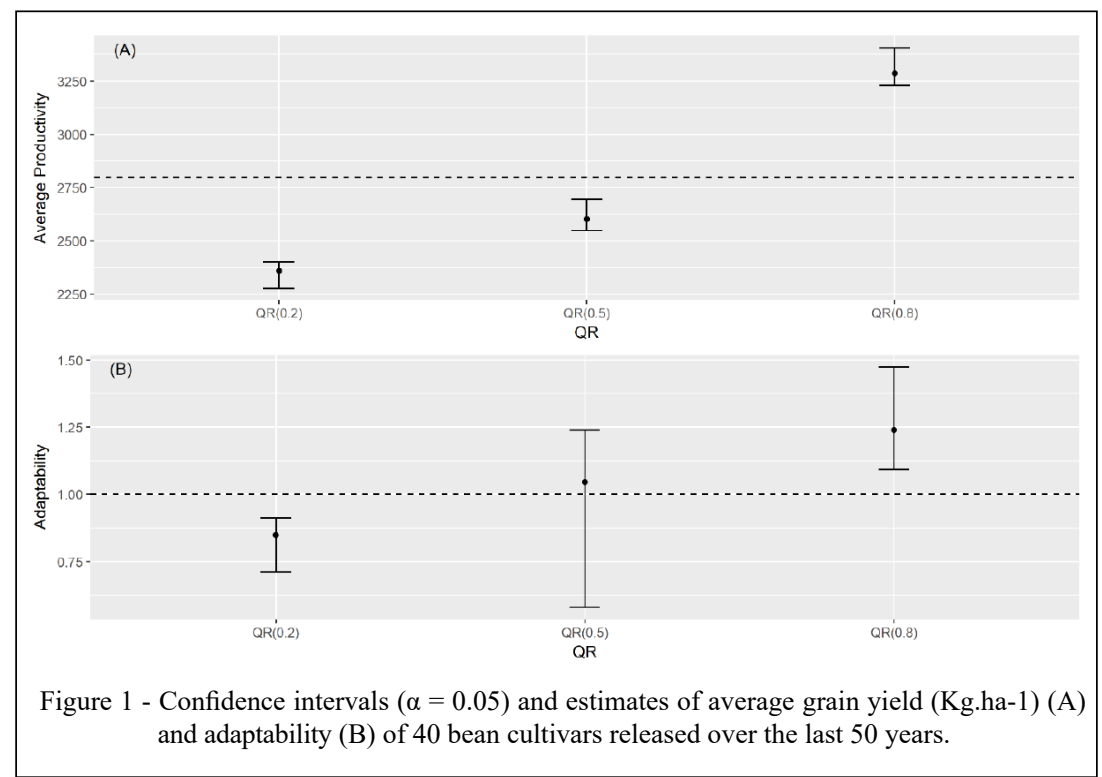

Ciência Rural, v.49, n.3, 2019. 


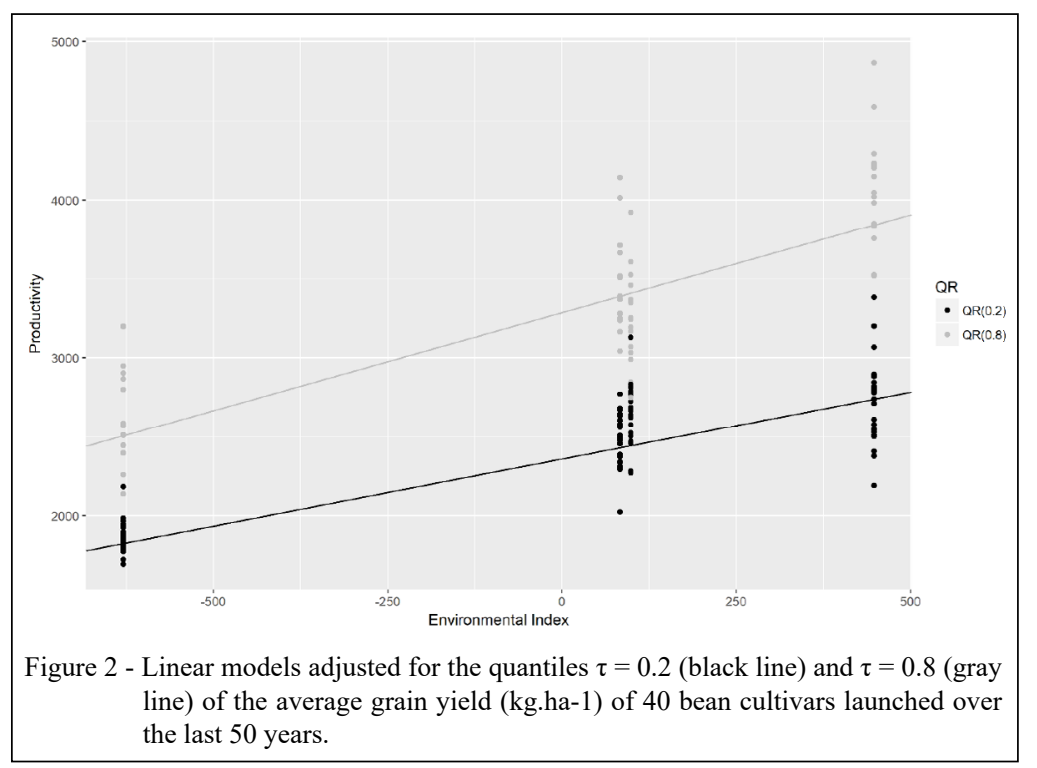

linked to the genetic improvement of beans. Studies on genetic progress conducted by MATOS et al. (2007), CHIORATO et al. (2010), FARIA et al. (2014), and BARILI et al. (2016) show genetic gains ranging between $1.07 \%$ and $3.26 \%$ per year.

It should be emphasized that, unlike the studies carried out by MATOS et al. (2007), CHIORATO et al. (2010), FARIA et al. (2014) and BARILI et al. (2016), the use of QR made it possible to obtain information about the effect of the adaptability parameter throughout the grain yield distribution; and therefore, how it changed over the last 50 years of genetic improvement.

\section{CONCLUSION}

The average productivity values and adaptability estimates of the recommended black bean cultivars over the last 50 years have an increasing behavior throughout this time span. The recently recommended cultivars were classified as belonging to the group $\mathrm{QR}_{0.8}$ indicating that these cultivars have higher grain yield and are more responsive to environmental improvement than those recommended until 1993.

\section{ACKNOWLEDGEMENTS}

The authors are grateful to the Coordenação de Aperfeiçoamento de Pessoal de Nível Superior (CAPES), for the doctoral scholarships of the first author.

\section{DECLARATION \\ OF \\ CONFLICTING INTERESTS}

The authors declare no conflict of interest. The founding sponsors had no role in the design of the study; in the collection, analyses, or interpretation of data; in the writing of the manuscript, and in the decision to publish the results.

\section{AUTHORS' CONTRIBUTIONS}

The authors contributed equally to the manuscript.

\section{REFERENCES}

BARILI, L.D. et al. Adaptability and stability and grain yield of black common bean cultivars used in Brazil in the last five decades. Ciência Rural, v. 45, n. 11, p. 1980-1986, 2015. Available from: $<$ http://dx.doi.org/10.1590/0103-8478cr20141383>. Accessed: Nov. 17, 2017. DOI: 10.1590/0103-8478cr20141383

BARILI, L.D. et al. Five decades of black common bean genetic breeding in Brazil. Pesquisa Agropecuária Tropical, v. 46, n. 3, p.259-266, 2016. Available from: <http://www.scielo.br/pdf/pat/ v46n3/1983-4063-pat-46-03-0259.pdf>. Accessed: Nov. 17, 2017. DOI: $10.1590 / 1983-40632016 v 4641371$.

BARROSO, L.M.A. et al. Methodology for analysis of adaptability and stability using quantile regression. Pesquisa Agropecuária Brasileira, v. 50, n. 4, p. 290-297, 2015. Available from: <https:// seer.sct.embrapa.br/index.php/pab/article/view/20187> . Accessed: Nov. 17, 2017. DOI: 10.1590/S0100-204X2015000400004.

CHIORATO, A.F. et al. Genetic gain in the breeding program of Applied Biotechnology, v.10, p.329-336, 2010. Available from: <http://www.scielo.br/pdf/cbab/v10n4/a07v10n4.pdf >. Accessed: Nov. 17, 2017. DOI: 10.1590/S1984-70332010000400007. 
CONAB (COMPANHIA NACIONAL DE ABASTECIMENTO). Acompanhamento de safra brasileira: grãos, nono levantamento, junho2017. Available from: <http://www.conab.gov.br/OlalaCMS/ uploads/arquivos/17_06_08_09_02_48_boletim_graos_ junho_2017.pdf>.Accessed: Nov. 17, 2017.

COUTO, M.F. et al. Eberhart and Russel's bayesian method in the selection of popcorn cultivars. Crop Science, v. 55, n. 2, p. 571-577, 2015. Available from: <https://dl.sciencesocieties. org $/$ publications $/$ cs/abstracts $/ 55 / 2 / 571$ ? access $=0 \& v i e w=p d f>$. Accessed: Nov. 17, 2017. DOI: 10.2135/cropsci2014.07.0498.

EBERHART, S.A.; RUSSELL, W.A. Stability parameters for comparing varieties. Crop Science, v.6, p.36-40, 1966. Available from: $<$ https://dl.sciencesocieties.org/publications/cs/abstracts/6/1/ CS0060010036>. Accessed: Nov. 17, 2017. DOI:10.2135/cropsci1 966.0011183X000600010011x.

FARIA, L.C. et al. Genetic progress during 22 years of black bean improvement. Euphytica, v. 199, n. 3, p. 261-272, 2014. Available from: <https://link.springer.com/article/10.1007/ s10681-014-1135-z>. Accessed: Nov. 17, 2017. DOI: 10.1007/ s10681-014-1135-z.

KOENKER, R. Confidence intervals for regression quantiles. In: Mandl P and Huskova M (Eds). Asymptotic statistics: proceedings of the 5th Prague Symposium. Physica-Verlag: Heidleberg. p 349-359, 1994. Available from: <https://link. springer.com/chapter/10.1007/978-3-642-57984-4_29>. Accessed: Dec. 30, 2018 .

KOENKER, R. et al. Package 'quantreg', Quantile Regression. R package version 5.33, 2017. Available from: $<$ https://cran.r-project. org/web/packages/quantreg/quantreg.pdf >. Assessed: Oct. 26, 2017.

KOENKER, R.; BASSET, G. Regression Quantiles. Econometrica, v.46, p.33-50, 1978. Available from: <http:// www.jstor.org/stable/1913643>. Accessed: May 30, 2018. DOI: $10.2307 / 1913643$.

MATOS, J.W. et al. Thirty two years of common bean breeding in Minas Gerais state. Ciência e Agrotecnologia, v.31 p.1749-1754, 2007. Available from: <http://www.scielo.br/pdf/cagro/v31n6/ a22v31n6.pdf $>$. Accessed: Nov. 17, 2017. DOI: 10.1590/S141370542007000600022 .
MOURA, M.M. et al. Potencial de caracteres na avaliação da arquitetura de plantas de feijão. Pesquisa Agropecuária Brasileira, v.48, n.4, p.417-425, 2013. Available from: <http:// www.scielo.br/pdf/pab/v48n4/10.pdf>. Accessed: Nov. 17, 2017. DOI: $10.1590 /$ S0100-204X2013000400010.

NASCIMENTO, M. et al. Quantile regression for genome-wide association study of flowering time-related traits in common bean. PLoS ONE, v.13, e0190303, 2018. Available from: <https://doi. org/10.1371/journal.pone.0190303>. Accessed: May 30, 2018. DOI: 10.1371 journal.pone.0190303.

PEREIRA, H.S. et al. Comparison of methods for phenotypic adaptability and stability analysis in common bean. Pesquisa Agropecuária Brasileira, v.44, p.374-383, 2009. Available from: $<$ http://www.scielo.br/pdf/pab/v44n4/a07v44n4.pdf $>$. Accessed: Nov. 17, 2017. DOI: 10.1590/S0100-204X2009000400007.

PUIATTI, G.A. et al. Quantile regression of nonlinear models to describe different levels of dry matter accumulation in garlic plants. Ciência Rural, v.48, 2018. Available from: <http://dx.doi. org/10.1590/0103-8478cr20170322>. Accessed: Jun. 05, 2018. DOI:10.1590/0103-8478cr20170322.

R Core Team. R: a language and environment for statistical computing. R Foundation for Statistical Computing, Vienna, Austria. 2018. Available from: $<$ https://www.r-project.org > Assessed: May. 27, 2018.

RAMALHO, M.A.P. et al. Contributions of plant breeding in Brazil - progress and perspectives. Crop Breeding and Applied Biotechnology, v. 12, p. 111-120, 2012. Available from: <http:// dx.doi.org/10.1590/S1984-70332012000500012>. Accessed: Nov. 20, 2017. DOI: 10.1590/S1984-70332012000500012.

RIBEIRO, N.D. et al. Adaptability and yield stability of common bean cultivars and elite lines in the State of Rio Grande do Sul. Ciência Rural, v.38, n.9, p.2434-2440, 2008. Available from: $<$ http://www.scielo.br/pdf/cr/v38n9/a18cr179.pdf $>$. Accessed: Nov. 20, 2017. DOI: 10.1590/S0103-84782008005000018.

SILVA, G.A.P. et al. Analysis of adaptability and yield stability in regional trials of common bean for the state of São Paulo, Brazil. Revista Ceres, v.60, p.59-65, 2013. Available from: <http://www. scielo.br/pdf/rceres/v60n1/09.pdf $>$. Accessed: Nov. 17, 2017. DOI: 10.1590/S0034-737X2013000100009. 